Prepared in cooperation with Colorado Springs City Engineering and Colorado Springs Utilities

\title{
Comparability Among Four Invertebrate Sampling Methods and Two Multimetric Indexes, Fountain Creek Basin, Colorado, 2010-2012
}

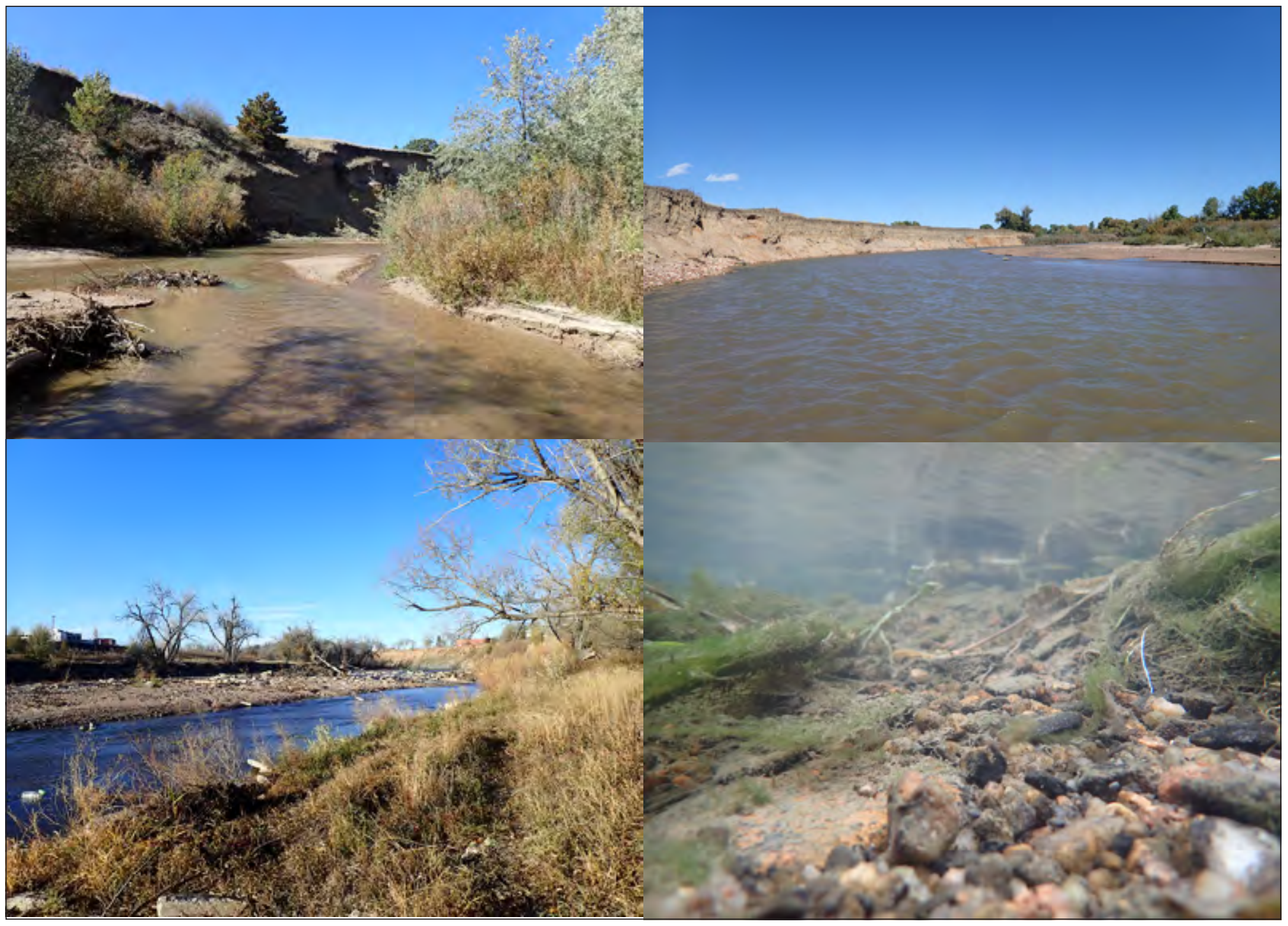

Scientific Investigations Report 2018-5061

U.S. Department of the Interior

U.S. Geological Survey 
Cover photographs. Top left. Upper end of sampling reach looking upstream, Monument Creek above Woodmen Road at Colorado Springs, Colorado. Top right. Middle of sampling reach looking upstream, Fountain Creek near Piñon, Colorado. Photographs by James J. Roberts, U.S. Geological survey.

Bottom left. Lower end of sampling reach on left bank looking upstream, Fountain Creek at Security, Colorado. Bottom right. Instream run habitat, Jimmy Camp Creek at Fountain, Colorado. Photographs by Erin J.P. Jeffery, U. S. Geological Survey. 


\section{Comparability Among Four Invertebrate Sampling Methods and Two Multimetric Indexes, Fountain Creek Basin, Colorado, 2010-2012}

By James F. Bruce, James J. Roberts, and Robert E. Zuellig

Prepared in cooperation with Colorado Springs City Engineering and Colorado

Springs Utilities

Scientific Investigations Report 2018-5061 


\title{
U.S. Department of the Interior \\ RYAN K. ZINKE, Secretary
}

\author{
U.S. Geological Survey \\ James F. Reilly II, Director
}

U.S. Geological Survey, Reston, Virginia: 2018

For more information on the USGS - the Federal source for science about the Earth, its natural and living resources, natural hazards, and the environment-visit https://www.usgs.gov or call 1-888-ASK-USGS.

For an overview of USGS information products, including maps, imagery, and publications,

visit https://store.usgs.gov.

Any use of trade, firm, or product names is for descriptive purposes only and does not imply endorsement by the U.S. Government.

Although this information product, for the most part, is in the public domain, it also may contain copyrighted materials as noted in the text. Permission to reproduce copyrighted items must be secured from the copyright owner.

Suggested citation:

Bruce, J.F., Roberts, J.J., and Zuellig, R.E., 2018, Comparability among four invertebrate sampling methods and two multimetric indexes, Fountain Creek Basin, Colorado, 2010-2012: U.S. Geological Survey Scientific Investigations Report 2018-5061, 11 p., https://doi.org/10.3133/sir20185061.

ISSN 2328-0328 (online) 


\section{Acknowledgments}

The authors thank Paul Foutz (Colorado Parks and Wildlife) and Travis Schmidt (U.S. Geological

Survey) who provided useful comments that improved earlier versions of this manuscript. 


\section{Contents}

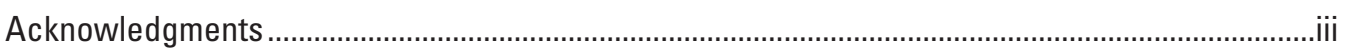

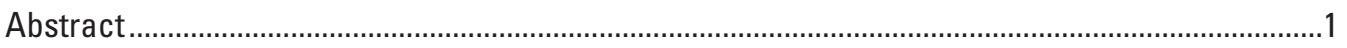

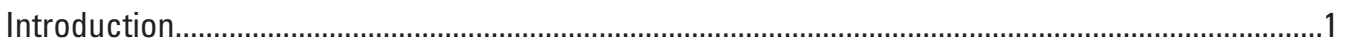

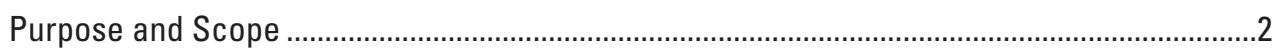

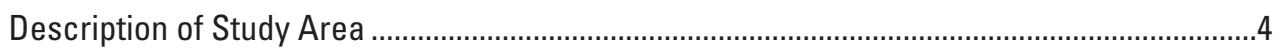

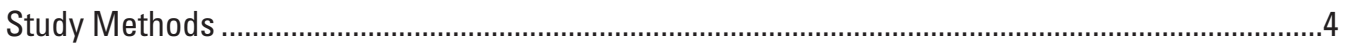

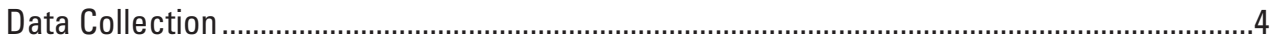

Multihabitat Sampling (Sampling Type) .........................................................................

USGS OMH (U.S. Geological Survey Qualitative Multihabitat Invertebrate Sampling Method) ......................................................................................

CDPHE Multi-Habitat (Colorado Department of Public Health and Environment

Multi-Habitat Invertebrate Sampling Method) ..............................................

Single-Habitat Sampling (Sampling Type) ...................................................................5

USGS RTH_Hess (Modified U.S. Geological Survey Richest-Targeted Habitat Invertebrate Sampling Method) .................................................................

CDPHE Riffle-Run (Colorado Department of Public Health and Environment RiffleRun Invertebrate Sampling Method) ...........................................................

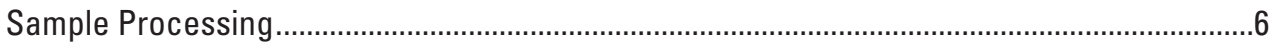

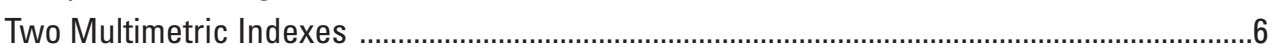

Comparability Among Four Sampling Methods and Two Multimetric Indexes ..................................

Comparison of Multimetric Index 2010 and Multimetric Index 2017 .......................................

Effects of Sample Type and Multimetric Index Version on Multimetric Index Values ...............8

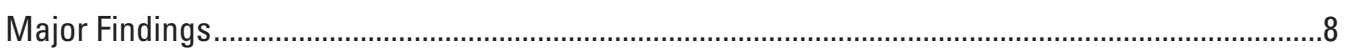

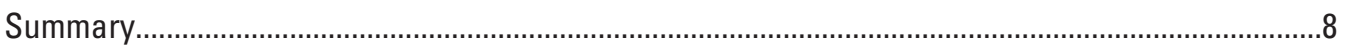

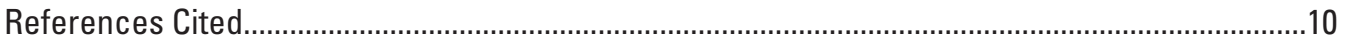

\section{Figures}

1. Map showing locations of sampling sites in the Fountain Creek Basin, Colorado, 2010-2012

2. Boxplot showing distributions of Multimetric Index-2010 values among U.S. Geological Survey and Colorado Department of Public Health and Environment sample methods

3. Boxplot showing distributions of Multimetric Index-2017 values among U.S. Geological Survey and Colorado Department of Public Health and Environment sample methods

4. Graph showing mean Multimetric Index values ( +1 standard error) calculated with the Multimetric Index-2017 from 204 multihabitat and single-habitat samples collected in 2010-2012 from 15 sites in the Fountain Creek Basin in Colorado.

5. Graph showing mean Multimetric Index (MMI) values (+1 standard error) comparing the MMI-2010 and MMI-2017 results from 102 single-habitat samples collected in 2010-2012 from 15 sites in the Fountain Creek Basin in Colorado.

6. Graph showing mean Multimetric Index (MMI) values (+1 standard error) comparing the MMI-2010 and MMI-2017 results from 102 multihabitat samples collected in 2010-2012 from 15 sites in the Fountain Creek Basin in Colorado. 


\section{Tables}

1. Description of sites and dates of sample collection from the Fountain Creek Basin, Colorado, 2010-2012...

2. Comparison of gear types and sampling effort used to collect invertebrate samples with U.S. Geological Survey and Colorado Department of Public Health and Environment protocols. .5

\section{Conversion Factors}

U.S. customary units to International System of Units

\begin{tabular}{lcl}
\hline \multicolumn{1}{c}{ Multiply } & By & \multicolumn{1}{c}{ To obtain } \\
\hline inch (in.) & \multicolumn{1}{c}{ Length } & \\
inch (in.) & 2.54 & centimeter $(\mathrm{cm})$ \\
inch (in.) & 25.4 & millimeter $(\mathrm{mm})$ \\
foot (ft) & 25,400 & micrometer $(\mathrm{mm})$ \\
\hline & 0.3048 & meter $(\mathrm{m})$ \\
\hline square foot $\left(\mathrm{ft}^{2}\right)$ & Area & \\
square mile $\left(\mathrm{mi}^{2}\right)$ & 0.09290 & square meter $\left(\mathrm{m}^{2}\right)$ \\
\hline
\end{tabular}

International System of Units to U.S. customary units

\begin{tabular}{|c|c|c|}
\hline Multiply & By & To obtain \\
\hline \multicolumn{3}{|c|}{ Length } \\
\hline micrometer $(\mu \mathrm{m})$ & 0.00003937 & inch (in.) \\
\hline \multicolumn{3}{|c|}{ Area } \\
\hline square meter $\left(\mathrm{m}^{2}\right)$ & 10.76 & square foot $\left(\mathrm{ft}^{2}\right)$ \\
\hline \multicolumn{3}{|c|}{ Volume } \\
\hline milliliter (ml) & 0.00211338 & pint (pt) \\
\hline
\end{tabular}

\section{Datum}

Vertical coordinate information is referenced to the North American Vertical Datum of 1988 (NAVD 88).

Elevation, as used in this report, refers to distance above the vertical datum. 


\section{Abbreviations}

$\begin{array}{ll}\text { ANOVA } & \text { analysis of variance } \\ \text { CDPHE } & \text { Colorado Department of Public Health and Environment } \\ \text { EDAS } & \text { Ecological Data Application System } \\ \text { FCB } & \text { Fountain Creek Basin } \\ \text { MMI } & \text { Multimetric Index } \\ \text { NAWOA } & \text { National Water-Quality Assessment Project } \\ \text { OMH } & \text { qualitative multihabitat } \\ \text { RTH } & \text { richest-targeted habitat } \\ \text { RTH_Hess } & \text { semiquantitative, richest-targeted habitat sample method } \\ \text { USGS } & \text { U.S. Geological Survey } \\ \text { WOCC } & \text { Water Quality Control Commission }\end{array}$




\title{
Comparability Among Four Invertebrate Sampling Methods and Two Multimetric Indexes, Fountain Creek Basin, Colorado, 2010-2012
}

\author{
By James F. Bruce, James J. Roberts, and Robert E. Zuellig
}

\section{Abstract}

The U.S. Geological Survey (USGS), in cooperation with Colorado Springs City Engineering and Colorado Springs Utilities, analyzed previously collected invertebrate data to determine the comparability among four sampling methods and two versions (2010 and 2017) of the Colorado Benthic Macroinvertebrate Multimetric Index (MMI). For this study, annual macroinvertebrate samples were collected concurrently (in space and time) at 15 USGS surface-water gaging stations in the Fountain Creek Basin from 2010 to 2012 using four sampling methods. The USGS monitoring project in the basin uses two of the methods and the Colorado Department of Public Health and Environment recommends the other two. These methods belong to two distinct sample types, one that targets single habitats and one that targets multiple habitats. The study results indicate that there are significant differences in MMI values obtained from the single-habitat and multihabitat sample types but methods from each program within each sample type produced comparable values. This study also determined that MMI values calculated by different versions of the Colorado Benthic Macroinvertebrate MMI are indistinguishable. This indicates that the Colorado Department of Public Health and Environment methods are comparable with the USGS monitoring project methods for single-habitat and multihabitat sample types. This report discusses the direct application of the study results to inform the revision of the existing USGS monitoring project in the Fountain Creek Basin.

\section{Introduction}

Invertebrate-based assessment of biological condition is often an integral component of water-quality monitoring programs (U.S. Environmental Protection Agency, 2006; Carlisle and Woodside, 2013). In 1998, the U.S. Geological Survey (USGS), in cooperation with Colorado Springs City Engineering and Colorado Springs Utilities, began sampling biological communities and selected water-quality characteristics in the Fountain Creek Basin (FCB) (fig. 1). Since 1998, the number of sites sampled each year has varied from 10 to 26 . During sampling, data are collected on invertebrate and fish communities, habitat, selected water-chemistry constituents, streamflow, and sediment transport. Several studies of the FCB have described patterns in surface-water hydrology (Stogner, 2000; Edelmann and others, 2002), water chemistry (Mau and others, 2007), and sediment transport (von Guerard, 1989). Other studies have related some of these patterns to urbanization and biological communities (Zuellig and others, 2007, 2010; Roberts and others, 2018a).

As the human population in the FCB increases, continued alteration of environmental characteristics in the FCB, especially surface-water hydrology, is expected. This increase in human population, in turn, could influence water quality, instream habitat, and ultimately, biological communities. Local, State, and Federal agencies are interested in acquiring a better understanding of the relations between environmental characteristics and biological communities in the FCB in order to inform water-resource management decisions and guide future monitoring activities.

In general, the Colorado Benthic Macroinvertebrate Multimetric Index (MMI) is a bioassessment tool developed for Colorado's flowing waters, which is designed to detect degrees of alteration in biological community structure. The Water Quality Control Commission (WQCC) of the Colorado Department of Public Health and Environment (CDPHE) used a variety of methods to develop the MMI, including stratifying sites, identifying benthic samples collected from reference and stressed sites, selecting nonredundant discriminating metrics, and incorporating individual metric scores into an index using an algorithm (CDPHE, WQCC, 2017).

In 2010 and 2017, the CDPHE recalibrated the MMI in the WQCC Policy 10-1 to assess the biological condition of small- to medium-size wadeable streams (that is, streams with a drainage area of less than 2,700 square miles) on the eastern slope of Colorado (CDPHE, WQCC, 2010, 2017). Invertebrate data used to build the MMIs were collected 
using various sampling methods, but samples collected with methods typically used by the CDPHE dominated the dataset. Therefore, use of the CDPHE sampling methods should be considered to appropriately apply the MMI to new data, as the sampling method used can influence detectability of certain taxa in community samples. Differences in sampling methods can influence sample comparability between sample types and possibly result in opposing assessments of biological condition, especially if MMI values are near established thresholds of impairment. Therefore, Colorado Springs City Engineering and Colorado Springs Utilities are concerned about data continuity if previously used sampling methods are replaced by methods currently used by the CDPHE to make assessments of biological condition.

Determining if differences in the sampling methods and MMI versions affect MMI scores and potentially change a biological assessment is important in making informed decisions on future biological sampling activities to be undertaken as part of the monitoring project in the FCB. For example, if samples are found comparable between sampling methods and MMI versions, then previously collected data can be retained or adjusted accordingly to make future trend assessments of invertebrate communities and biological condition over the entire period of the monitoring project. Alternatively, if samples are found to be not comparable or cannot be adjusted, then methods used since 1998 could be replaced by current methods developed by the CDPHE; as a result, previously collected data would not be considered in future trend assessments unless additional resources are available to collect samples using all four methods.

To address these issues, the USGS, in cooperation with Colorado Springs City Engineering and Colorado Springs Utilities, analyzed previously collected invertebrate data to determine if sampling methods and MMI values calculated with different versions (2010 and 2017) of the MMI are comparable. This study collected annual macroinvertebrate samples concurrently (in space and time) at 15 USGS surfacewater gaging stations in the FCB from 2010 to 2012. Four sampling methods were used, two USGS methods and two methods recommended by the CDPHE.

\section{Purpose and Scope}

The purpose of this report is to evaluate the comparability among four invertebrate sampling methods and two versions of the MMI (hereafter, MMI-2010 and MMI-2017); the sampling methods were used to collect samples at 15 selected sites in the FCB from 2010 to 2012 (see table 1 and fig. 1). Invertebrate samples were collected concurrently (in space and time) using multiple- and single-habitat sampling protocols used by the USGS project and those developed by the CDPHE for the MMI.

Table 1. Description of sites and dates of sample collection from the Fountain Creek Basin, Colorado, 2010-2012.

[Site identification numbers, names, and site data are from the U.S. Geological Survey BioData database at https://doi.org/doi:10.5066/F77W698B and National Water Information System database at https://doi.org/10.5066/F7P55KJN—search by USGS station identification number (USGS, 2017 a, b). ID, identification; USGS, U.S. Geological Survey; NAVD 88, North American Vertical Datum of 1988; ft, foot; mi², square mile; m, meter; CO., Colorado; bl, below; USAF, U.S. Air Force Academy; Cr, creek; abv, above; Trib, tributary; Sprg, Springs; blw, below]

\begin{tabular}{|c|c|c|c|c|c|c|c|c|}
\hline \multirow{2}{*}{$\begin{array}{l}\text { Site } \\
\text { ID }^{1}\end{array}$} & \multirow{2}{*}{$\begin{array}{c}\text { USGS station } \\
\text { ID }\end{array}$} & \multirow{2}{*}{ USGS station name } & \multirow{2}{*}{$\begin{array}{c}\text { Elevation } \\
\text { NAVD } 88 \text { (ft) }\end{array}$} & \multirow{2}{*}{$\begin{array}{l}\text { Drainage } \\
\text { area }\left(\mathrm{mi}^{2}\right)\end{array}$} & \multirow{2}{*}{$\begin{array}{c}\text { Reach length } \\
\text { (m) }\end{array}$} & \multicolumn{3}{|c|}{ Dates of sample collection } \\
\hline & & & & & & 2010 & 2011 & 2012 \\
\hline 1 & 07103700 & $\begin{array}{l}\text { Fountain Creek near Colorado } \\
\text { Springs, Co. }\end{array}$ & 6,110 & 103 & 150 & $10 / 21 / 2010$ & $10 / 17 / 2011$ & $9 / 10 / 2012,10 / 24 / 2012$ \\
\hline 2 & 07103707 & $\begin{array}{l}\text { Fountain Creek bl 8th St. at } \\
\text { Colorado Springs, Co. }\end{array}$ & 6,000 & 119 & 150 & $10 / 21 / 2010$ & $10 / 17 / 2011$ & $9 / 10 / 2012$ \\
\hline 3 & 07103960 & $\begin{array}{l}\text { Kettle Creek above USAF } \\
\text { Academy, Co. }\end{array}$ & 6,620 & 16 & 100 & $10 / 19 / 2010$ & $10 / 13 / 2011$ & $9 / 7 / 2012$ \\
\hline 4 & 07103970 & $\begin{array}{l}\text { Monument } \mathrm{Cr} \text { abv Woodmen } \mathrm{Rd} \text { at } \\
\text { Colorado Springs, Co. }\end{array}$ & 6,270 & 181 & 150 & $10 / 19 / 2010$ & $10 / 17 / 2011$ & $9 / 10 / 2012$ \\
\hline 5 & 07103990 & $\begin{array}{l}\text { Cottonwood Creek at Mouth at } \\
\text { Pikeview, Co. }\end{array}$ & 6,265 & 18.7 & 150 & $10 / 19 / 2010$ & $10 / 13 / 2011$ & $9 / 7 / 2012,10 / 23 / 2012$ \\
\hline 6 & 385124104501301 & $\begin{array}{l}\text { Monument Cr Trib } 2 \text { at Sondermann } \\
\text { Park at Colo Sprg }\end{array}$ & 6,060 & 2.04 & 100 & $10 / 22 / 2010$ & $10 / 13 / 2011$ & $9 / 7 / 2012,10 / 23 / 2012$ \\
\hline 7 & 07104905 & $\begin{array}{l}\text { Monument Creek at Bijou St. at } \\
\text { Colo. Springs, Co. }\end{array}$ & 5,980 & 235 & 250 & $10 / 19 / 2010$ & $10 / 17 / 2011$ & $9 / 10 / 2012$ \\
\hline 8 & 384909104504401 & $\begin{array}{l}\text { Bear Cr above } 8 \text { th Street at } \\
\text { Colorado Springs, Co. }\end{array}$ & 6,037 & 9.57 & 150 & $10 / 22 / 2010$ & $10 / 13 / 2011$ & $9 / 11 / 2012$ \\
\hline 9 & 07105500 & $\begin{array}{l}\text { Fountain Creek at Colorado } \\
\text { Springs, Co. }\end{array}$ & 5,900 & 392 & 175 & $10 / 21 / 2010$ & $10 / 14 / 2011$ & $9 / 10 / 2012$ \\
\hline 10 & 07105530 & $\begin{array}{l}\text { Fountain Cr blw Janitell Rd blw } \\
\text { Colo. Springs, Co. }\end{array}$ & 5,840 & 413 & 300 & $10 / 20 / 2010$ & $10 / 14 / 2011$ & $9 / 11 / 2012$ \\
\hline 11 & 07105800 & Fountain Creek at Security, Co. & 5,640 & 495 & 300 & $10 / 21 / 2010$ & $10 / 18 / 2011$ & $9 / 11 / 2012,10 / 24 / 2012$ \\
\hline 12 & 07105900 & Jimmy Camp Creek at Fountain, Co. & 5,530 & 65.6 & 150 & $10 / 18 / 2010$ & $10 / 18 / 2011$ & $9 / 6 / 2012,10 / 23 / 2012$ \\
\hline 13 & 07106000 & Fountain Creek near Fountain, Co. & 5,355 & 681 & 300 & $10 / 18 / 2010$ & $10 / 12 / 2011$ & $9 / 11 / 2012$ \\
\hline 14 & 07106300 & Fountain Creek near Pinon, Co. & 4,990 & 849 & 300 & $10 / 20 / 2010$ & $10 / 14 / 2011$ & $9 / 11 / 2012$ \\
\hline 15 & 07106500 & Fountain Creek at Pueblo, Co. & 4,705 & 926 & 300 & $10 / 20 / 2010$ & $10 / 12 / 2011$ & $9 / 11 / 2012,10 / 24 / 2012$ \\
\hline
\end{tabular}

${ }^{1}$ See figure 1 . 


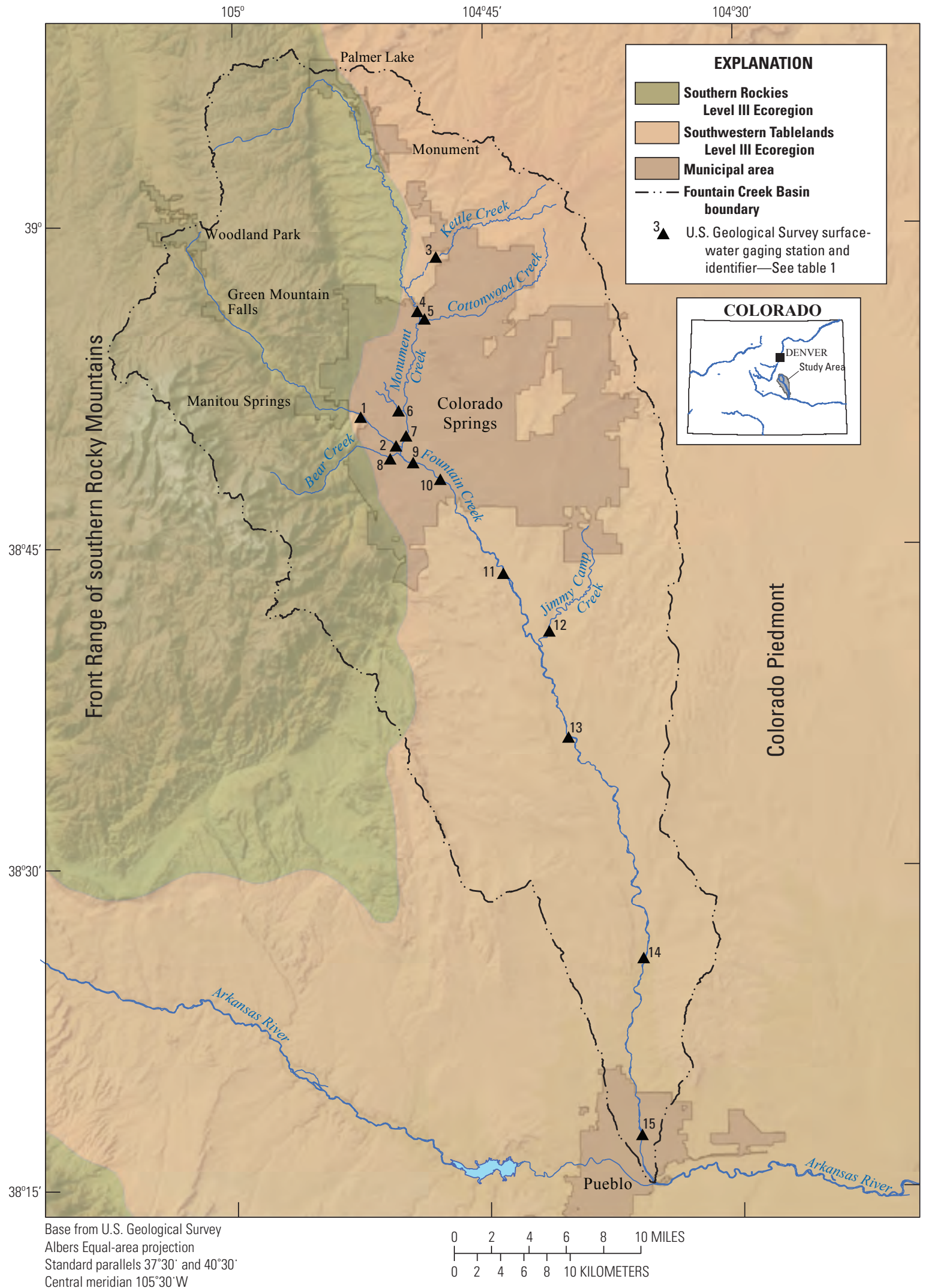

Figure 1. Locations of sampling sites in the Fountain Creek Basin, Colorado, 2010-2012. 


\section{Description of Study Area}

Several previous studies (Edelmann and others, 2002; Mau and others, 2007; Zuellig and others, 2007) describe the FCB and the sites included in the study area (fig. 1). In general, the FCB is in south-central Colorado and encompasses approximately 926 square miles draining the eastern slope of the Rocky Mountains (fig. 1). Elevation ranges from 4,700 feet at the confluence with the Arkansas River to 14,109 feet at the summit of Pikes Peak. Fountain and Monument Creeks, the two main drainages, are located in the transition zone of two distinctive physiographic landforms: the Front Range of the Southern Rocky Mountains and the Colorado Piedmont (Hansen and Crosby, 1982). These landforms correspond to two Level III ecoregions, the Southern Rockies and the Southwestern Tablelands (Omernik, 1987). However, the sites included in this study were restricted to the Southwestern Tablelands (fig. 1). Site elevations range from 4,705 to 6,620 feet (referenced to North American Vertical Datum of 1988) and drainage areas range from 2.04 to 926 square miles (table 1).

\section{Study Methods}

The USGS FCB monitoring project specifies two stream invertebrate sample types: a qualitative multihabitat sample (hereafter, QMH) described in the protocols of the USGS National Water-Quality Assessment Program Project (NAWQA; Cuffney and others, 1993; Moulton and others, 2002) and a slightly modified NAWQA semiquantitative richest-targeted habitat (RTH) sample (hereafter, $\mathrm{RTH}_{-}$Hess). Briefly, for a QMH sample, organisms are collected from all available habitat types within the stream reach for 1 hour using a D-frame net. For the USGS FCB monitoring project, the NAWQA RTH sample described in Cuffney and others (1993) was modified slightly to better match methods used in the FCB prior to 1998 by Colorado Springs Utilities. Modifications included sampling less of the stream bottom area and using a Hess sampler instead of a slack sampler (Moulton and others, 2002). The USGS project has consistently used these methods in the FCB since 1998.

Similarly, CDPHE sampling methods include two sample types: a semi-quantitative sample collected in soft-bottomed streams where the targeted habitats are woody snags, pools, and macrophyte beds (hereafter, CDPHE Multi-habitat) and a semiquantitative sample targeting riffle or run habitats in hardbottomed streams (hereafter, Riffle-run) (CDPHE 2010, 2017).

Many sites (reaches) included in this study were dominated by soft-bottomed material (sand) but often included sparse riffles containing harder substrate (gravel and sometimes larger particles). Strict interpretation of the CDPHE methods would only require collecting a CDPHE Multi-habitat sample targeting woody snags, pools, and macrophyte beds. However, to address the objectives of this study adequately, all four sample types were collected at each site and during each visit to compare the different sample methods. As a result, 204 invertebrate samples were collected concurrently (in space and time) from 2010 to 2012 from 15 sites using the four sample methods.

Various combinations of these data were analyzed using analysis of variance (ANOVA) and routines detailed in the following sections and in Zuellig and others (2014). The USGS Biological Group (BioGroup) of the National Water Quality Laboratory (Lakewood, Colorado) provided quality control of the invertebrate samples; the laboratory determined sorting effectiveness and taxonomic accuracy for a minimum of 5 percent of samples each year. Quality-control results from 2010 indicated that mean sorting effectiveness was 96.9 percent and mean taxonomic accuracy based on the Jaccard Coefficient of Community (Jaccard, 1912) and Sorensen's Coefficient of Community (Sorensen, 1948) were 87.0 and 97.7 percent, respectively.

The most commonly missed taxa were immature specimens, especially Naididae (aquatic naidids) and Acari (mites). In 2011, the BioGroup completed a verification of the reference collection maintained by a contract laboratory (Aquatic Associates Inc., Fort Collins, Colo.). The BioGroup agreed with the original determination for 312 of the 329 taxa in the reference collection. The differences for the remaining 17 taxa included 4 nomenclature issues, 12 determinations that were taxonomic name upgrades or downgrades, and 1 misidentification. Quality control results from 2012 indicated that mean sorting effectiveness was 99.7 percent, and mean taxonomic accuracy based on the Jaccard Coefficient of Community (Jaccard, 1912) and Sorensen's Coefficient of Community (Sorensen, 1948) were 91.0 and 96.0 percent, respectively.

The invertebrate data are available at the USGS Aquatic Bioassessment Data for the Nation (BioData) website (https:// doi.org/doi:10.5066/F77W698B) by searching for a USGS station identification number (see table 1). The invertebrate data and calculated indices generated during this study are available as a USGS data release (Roberts and others, 2018b).

\section{Data Collection}

Invertebrates were sampled each year (2010, 2011, and 2012) during base-flow conditions (time-of-year when streamflow is usually dominated by groundwater seepage) between September and October (table 1). During each site visit, samples were collected using all four sample methods concurrently (in space and time) following modified NAWQA (Cuffney and others, 1993) and CDPHE (CDPHE, WQCC, 2010) protocols. The four invertebrate sampling methods are discussed in the following sections. 


\section{Multihabitat Sampling (Sample Type)}

\section{USGS QMH (U.S. Geological Survey Qualitative Multihabitat Invertebrate Sampling Method)}

The USGS QMH sampling method uses a D-frame kick net equipped with a 500-micrometer $(\mu \mathrm{m})$ (or 0.02-inch) mesh to collect organisms for 1 hour from all available habitat types within a stream reach (table 2; Cuffney and others, 1993). Different habitat types were identified, their contributing area of the reach in relative occurrence was calculated, and the matching fraction of 1 hour was spent sampling each associated habitat type. For example, if the reach was 50 percent run, 25 percent pool, and 25 percent riffle, the run habitat was sampled for approximately 30 minutes and the pool and riffle habitats were sampled for approximately 15 minutes each. Sampling effort (Zuellig and others, 2014) with this method did not always conform to these strict guidelines; this nonconformance was mostly because of the small stream size and the lack of heterogeneous habitat and substrate typical at FCB sites. Often the entire reach and each habitat type were adequately sampled in less than 60 minutes.

\section{CDPHE Multi-Habitat (Colorado Department of Public Health and Environment Multi-Habitat Invertebrate Sampling Method)}

A kick net equipped with a $500-\mu \mathrm{m}$ (or 0.02 -inch) mesh was used to collect the CDPHE recommended semiquantitative multihabitat samples from woody debris or snags, bank margins, pools, and aquatic macrophytes (WQCC Policy 10-1; CDPHE, WQCC, 2010). The sampling effort for this method is defined as the active collection of organisms over an area of approximately 1 square meter $\left(\mathrm{m}^{2}\right)$ (or 10.76 square feet $\left[\mathrm{ft}^{2}\right]$ ) for a total of 60 seconds (table 2).

Table 2. Comparison of gear types and sampling effort used to collect invertebrate samples with U.S. Geological Survey (USGS) and Colorado Department of Public Health and Environment (CDPHE) protocols.

[N, no; $\mathrm{m}^{2}$, square meter; $\mathrm{s}$, seconds; $\mathrm{Y}$, yes]

\begin{tabular}{llll}
\hline $\begin{array}{c}\text { Sample types and } \\
\text { methods }\end{array}$ & \multicolumn{1}{c}{ Gear } & Composite & Effort \\
\hline \multicolumn{4}{c}{ Multihabitat } \\
\hline USGS QMH $^{1}$ & D-Frame dip net & $\mathrm{N}$ & up to 60 minutes \\
CDPHE Multi-habitat ${ }^{2}$ & Kick net & $\mathrm{N}$ & $\begin{array}{c}\text { approximately } \\
1 \mathrm{~m}^{2}, 60 \mathrm{~s}\end{array}$ \\
& & &
\end{tabular}

\begin{tabular}{llll}
\hline \multicolumn{3}{c}{ Single habitat } \\
\hline USGS RTH_Hess $^{3}$ & Hess sampler & Y & $0.26 \mathrm{~m}^{2}$ \\
CDPHE Riffle-run $^{4}$ & Kick net & $\mathrm{N}$ & $0.91 \mathrm{~m}^{2}, 60 \mathrm{~s}$ \\
\hline
\end{tabular}

${ }^{1}$ Qualitative multihabitat invertebrate sample.

${ }^{2}$ Multihabitat, soft-bottomed stream invertebrate sample.

${ }^{3}$ Semiquantitative, richest-targeted habitat sample.

${ }^{4}$ Hard-bottomed stream invertebrate sample.
In general, the kick net was jabbed and swept through the targeted habitats by one person as another person timed the sampling effort. A maximum of four habitats were targeted for this sampling at each site. If only one habitat was identified within a reach, it was sampled for 60 seconds and the area was restricted to the width of the net's frame and the length of the net. If multiple habitats were identified in the reach, the sampling time and area were reduced by the fraction of total habitats. For example, if three habitats were selected for sampling, then each habitat was sampled for 20 seconds and the area was limited to the width of the net's frame and one-third the length of the net. Two USGS personnel always collected the samples to ensure that the sampling effort among samples was consistent among sites. The application of this method in this study excluded hard-bottomed riffle and run habitats (if present), because this method as described by the CDPHE is exclusive to soft-bottomed streams where riffles and runs are typically absent.

\section{Single-Habitat Sampling (Sample Type)}

\section{USGS RTH_Hess (Modified U.S. Geological Survey Richest-Targeted Habitat Invertebrate Sampling Method)}

To maintain continuity with invertebrate data collected prior to 1998 in the FCB, the sampling gear, area sampled (effort), and randomization used for RTH_Hess sampling slightly departs from the NAWQA RTH protocols described in Cuffney and others (1993) and Moulton and others (2002). In general, a Hess sampler $\left(0.086 \mathrm{~m}^{2}\right.$ or $\left.0.923 \mathrm{ft}^{2}\right)$ equipped with a $500-\mu \mathrm{m}$ (or 0.02-inch) mesh was used to collect macroinvertebrates from three points within the RTH (Cuffney and others, 1993). For this study, the collections were made in riffles or runs with coarse substrate (table 2). Three discrete collections from the three points were composited and yielded a total area of $0.26 \mathrm{~m}^{2}\left(2.80 \mathrm{ft}^{2}\right)$ per sample (table 2). The USGS project in the FCB targets riffle habitat at all sites; however, where riffles are absent because of unstable substrate, runs with the coarsest substrate were sampled. A random numbers table was used to determine the number of steps from the downstream boundary for the three sample points within the length of the selected RTH (riffle or run). If the randomly selected point occurred outside the boundary of the RTH, the point was rejected and replaced with an alternative randomly generated point. If a sample point could not be sampled because the substrate exceeded the limit of the sampler, the point was moved laterally or upstream one step.

Attempts were made to sample the same habitat type at each site every year, but in Fountain Creek, runs and riffles are not spatially stable because of streambed alteration caused by stormflow events and episodic utility construction activities within the channel. Samples were collected in a downstream to upstream direction. The Hess sampler was pushed firmly into the streambed and the substrate was mixed to dislodge invertebrates. When present, cobbles were scrubbed inside the sampler to further remove clinging invertebrates and inspected 
for remaining invertebrates. The remaining substrate within the sampler was stirred by hand or a sturdy metal utensil to a depth of approximately 0.10 meters $(\mathrm{m})$ (about 4 inches) to dislodge invertebrates from the smaller substrate and those dwelling within the substrate. There was no time constraint for collecting this sample as there is for the other methods used in this study.

\section{CDPHE Riffle-Run (Colorado Department of Public Health} and Environment Riffle-Run Invertebrate Sampling Method)

As specified in the 2010 WQCC Policy 10-1 (CDPHE, WQCC, 2010), a kick net equipped with a $500-\mu \mathrm{m}$ (or 0.02inch) mesh was used to collect CDPHE Riffle-run samples in the same riffle or run as the USGS RTH_Hess samples. Because the net was large and to ensure the sample effort limit was achieved, two USGS personnel collected all of these samples. As defined in Policy 10-1, the area of this sample $\left(0.91 \mathrm{~m}^{2}\right.$ or $9.75 \mathrm{ft}^{2}$; table 2$)$ is the total length of the kick net handle ( $1.98 \mathrm{~m}$ or 78 inches) multiplied by the width of the net's rectangular frame $(0.46 \mathrm{~m}$ or 18 inches). After placing the kick net firmly against the streambed, the net handle was lowered upstream horizontally over the water surface. The upstream point where the end of the kick net handle reached delineated the upstream boundary of the sample location. Next, one person held the net handle upright and timed the collection of the sample. The other person began disturbing the substrate with their boots and scrubbing cobbles in an upstream direction within the limit of the sample area until the net holder signaled the end of 60 seconds. The sample was complete and the net was removed from the streambed after the plume of discolored water disappeared. These samples were collected immediately upstream, downstream, or in-between the three USGS RTH_Hess sample locations. One of these four sample locations (one CDPHE Riffle-run and three USGS RTH_Hess samples) was determined randomly at the beginning of each day and then at subsequent sites this randomly determined position was moved one position upstream. For example, if the CDPHE Riffle-run sample was randomly determined to be at location 2 at the first site of the day, then at the next site, the Riffle-run sample would be collected upstream at location 3 .

\section{Sample Processing}

Samples often contained a considerable amount of inorganic and organic debris that was reduced in the field by elutriating and sieving the debris (in a 500- $\mu \mathrm{m}$ [or 0.02-inch] mesh-metal sieve) until sample volumes were approximately 500 milliliters (about 1 pint). Samples were preserved in the field with 10-percent formalin and stored until delivered to the contract laboratory for sample processing and taxa identification (Klemm and others, 1990). All organisms were identified to the lowest possible taxonomic resolution and enumerated. The fixed-count subsample target in the laboratory was 300 organisms per sample; when organisms were more numerous, a subsampling frame was used to select organisms randomly until the 300 fixed-count was achieved.

\section{Two Multimetric Indexes}

The MMI values were calculated using a bioassessment tool designed for the CDPHE (Jessup, 2010; Jessup and Stribling, 2017; MMI-2010 and MMI-2017, respectively) to assess the biological condition of streams in Colorado and evaluate State aquatic life use designations (CDPHE, WQCC, 2010, 2017). The tool is packaged in a Microsoft Access ${ }^{\circledR}$ database as the Ecological Data Application System (EDAS) for Colorado. Details of how the MMIs were developed and recalibrated are described in detail elsewhere (CDPHE, WQCC, 2010, 2017; Jessup, 2010; Jessup and Stribling, 2017). In general, the MMI values calculated using MMI-2010 and MMI-2017 were similar in that, for Colorado, EDAS calculated the MMI values from an internal list of operational taxonomic units using sets of metrics that best distinguished between reference and stressed sites in three designated site classes or Biotypes. These EDAS Biotypes are defined as (1) Transitional, (2) Mountains, and (3) Plains. All of the FCB sites included in this study were classified as Biotype 3 or Plains. The EDAS Biotype 3 streams for Colorado are generally characterized by low elevation, low gradient, warm water, and a dry climate relative to the other two Biotypes. Furthermore, both versions of the Colorado MMI randomly subsample samples with more than 360 individual organisms to achieve a 300 count.

There are four notable differences between the MMI2010 and MMI-2017 for Biotype 3 sites (CDPHE, WQCC, 2010, 2017; Jessup, 2010; Jessup and Stribling, 2017).

- First, the MMI-2010 was built with three environmental predictor variables (ecoregion, elevation, and stream gradient) that were used in a multivariate combination to identify the Biotype of a site. The MMI-2017 used two additional environmental variables (summer air temperature and day-of-year) to distinguish the Biotype of a site and adjust the calculation of some metrics.

- Second, the MMI-2010 includes six metrics: (1) number of insect taxa, (2) percent noninsect taxa, (3) percent dominant taxon, (4) number of predator and shredder taxa combined, (5) percent sprawler, and (6) percent sensitive Plains families. The MMI2017 includes eight metrics, only three of which are in common with MMI-2010: (1) total taxa; (2) percent noninsect taxa; (3) percent Ephemeroptera (mayflies), Plecoptera (stoneflies), and Trichoptera (caddisflies), excluding Baetidae (small minnow mayflies);

(4) percent sprawler; (5) number of intolerant taxa; (6) percent increaser Plains individuals; (7) number of 
predator or shredder taxa combined; and (8) percent scraper individuals.

- Third, the sampling index periods for MMI-2010 and MMI-2017 are May 1 to October 1, and May 1 to November 30 , respectively.

- Fourth, the Biotype 3 thresholds of biological attainment and impairment for MMI-2010 are 37 and 22, respectively, compared to the MMI-2017 thresholds, which are 42 and 29.

\section{Comparability Among Four Sampling Methods and Two Multimetric Indexes}

Prior to statistical analysis, all of the MMI values passed the tests of normality and equal variance so these data were not transformed. Parametric one-way and twoway ANOVA tests were used to evaluate the comparability between the MMI-2010 and MMI-2017 values and assess the comparability among sampling methods. Zuellig and others (2014) previously demonstrated with multivariate analyses of whole-community data (taxa lists) that multihabitat (USGS QMH and CDPHE Multi-habitat) and single-habitat (USGS RTH_Hess and CDPHE Riffle-run) sample types capture somewhat different compilations of taxa; however, sample methods from within sample types were indistinguishable, suggesting CDPHE and USGS methods within sample types are comparable. Because the taxa list remained unchanged, it was not necessary to repeat these analyses (see Zuellig and others, 2014). The following sections provide detailed descriptions of these analyses. All analyses were done using SYSTAT ${ }^{\circ} 12$ software (SYSTAT Software Inc., San Jose, California) using a significance threshold of $\alpha=0.05$ (probability $[p]$ less than 0.05 ). The F-ratio is the test statistic from the ANOVA tests; values near 1 indicate that there is no statistical difference between the distributions.

\section{Comparison of Multimetric Index 2010 and Multimetric Index 2017}

To compare the MMI values calculated using the different versions of the MMI (MMI-2010 and MMI-2017), two one-way ANOVA tests were performed with sample method as the factor being evaluated. These results were used to compare the MMI values obtained using the four different sample methods and were calculated with both versions of the MMI. A Tukey post-hoc comparison test was also used to compare specific differences among all sample methods (that is, USGS QMH, CDPHE Multi-habitat, USGS RTH_Hess, and CDPHE Riffle-run).

Significant differences ( $p$ less than 0.001) were found between the mean MMI values obtained from multihabitat and single-habitat sample types, but the sample methods within the sample types were statistically indistinguishable using the MMI-2010 and MMI-2017 values (figs. 2 and 3). There was also a consistent pattern showing that the multihabitat sample type methods produced greater MMI values than the single-habitat sample type methods. These results indicate that the different sample types produce significantly different MMI values and that these results are comparable between the USGS and CPDHE sample methods within the multihabitat (USGS QMH or CDPHE Multi-habitat) or single-habitat (USGS RTH_Hess or CDPHE Riffle-Run) sample types. These results also indicate that the values from the MMI2017 version do not change the conclusion, initially made by Zuellig and others (2014), that the USGS and CPDHE sample methods are comparable.

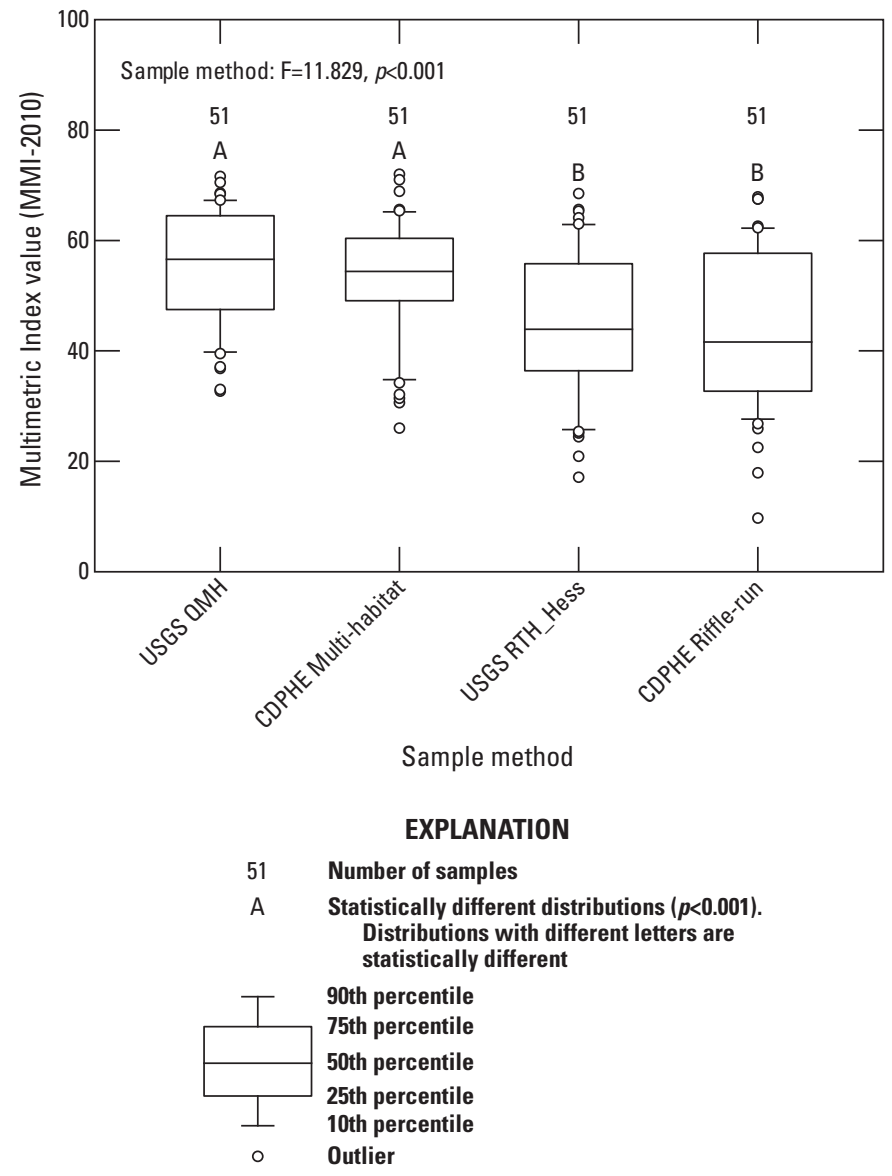

Figure 2. Distributions of Multimetric Index-2010 values among U.S. Geological Survey (USGS) and Colorado Department of Public Health and Environment (CDPHE) sample methods. (Sample methods are USGS OMH—qualitative multihabitat invertebrate sample; CDPHE Multi-habitat-multihabitat, soft-bottomed stream invertebrate sample; USGS RTH_Hesssemiquantitative, richest-targeted habitat sample; and CDPHE Riffle-run —hard-bottomed stream invertebrate sample. MMI, Multimetric Index; F, F-ratio; p, probability; <, less than) 


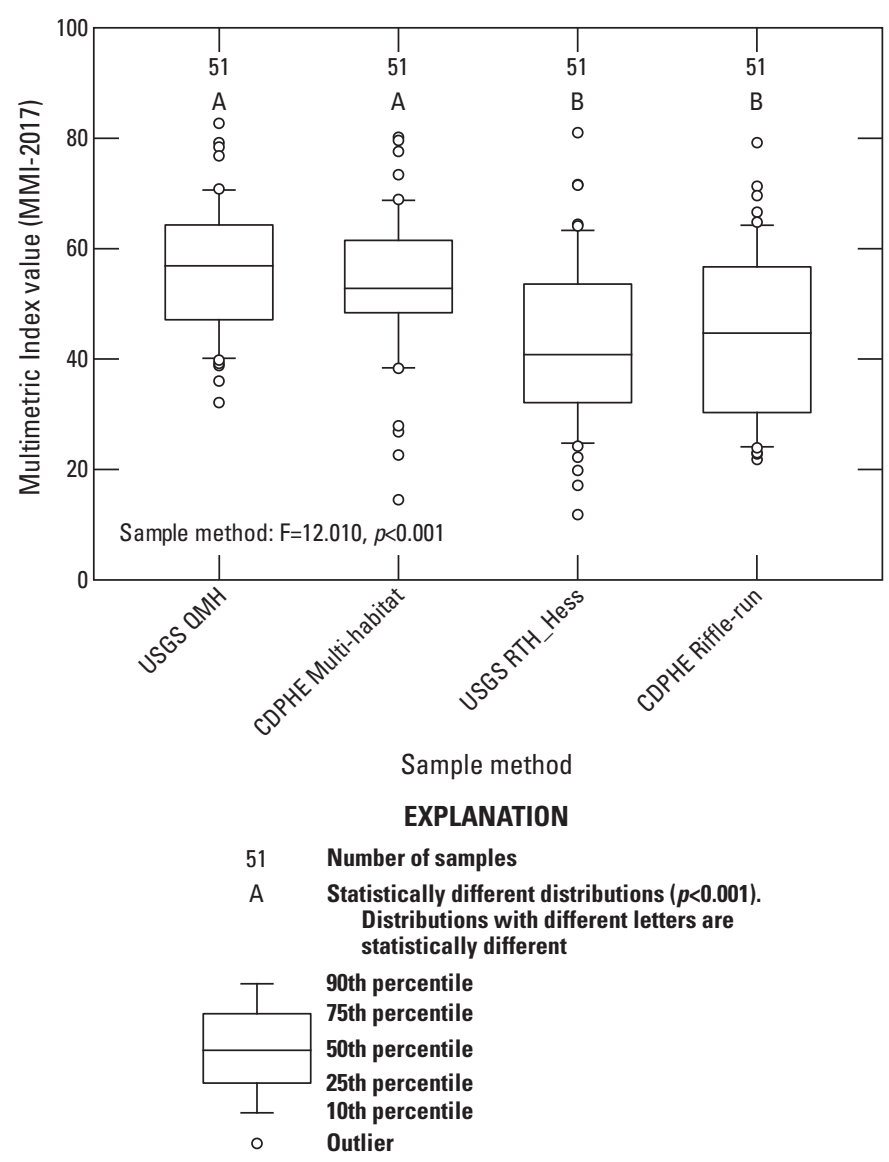

Figure 3. Distributions of Multimetric Index-2017 values among U.S. Geological Survey (USGS) and Colorado Department of Public Health and Environment (CDPHE) sample methods. (Sample methods are USGS OMH—qualitative multihabitat invertebrate sample; CDPHE Multi-habitat-multihabitat, soft-bottomed stream invertebrate sample; USGS RTH_Hesssemiquantitative, richest-targeted habitat sample; and CDPHE Riffle-run-hard-bottomed stream invertebrate sample. MMI, Multimetric Index;-F, F-ratio; p, probability; <, less than)

\section{Effects of Sample Type and Multimetric Index Version on Multimetric Index Values}

To compare how MMI values vary by sample type (that is, multihabitat and single-habitat sample types), one two-way ANOVA test was performed with the MMI-2017 values. The factors for the two-way ANOVA test were (1) sample type and (2) site. To compare differences between the MMI versions, two two-way ANOVA tests were performed, one ANOVA test for each sample type (that is, multihabitat and single-habitat sample types). The factors for these ANOVA tests were (1) MMI version and (2) site. The site factor was found to be significantly different ( $p$ less than 0.001) in all of the ANOVA tests. This difference was expected because of the variability in habitats and flows experienced across the sites included in this study. Interpreting the significance of the site factor is beyond the scope of this report. Furthermore, the interaction factor in all of the ANOVA tests were not significant ( $p$ greater than 0.5 ), which allowed for the simple interpretation of the main factors.

The two-way ANOVA test with sample type and site as factors indicates that the mean MMI-2017 values are significantly different ( $p$ less than 0.001 ) for the samples collected using multihabitat and single-habitat sample types (fig. 4). The mean MMI value from multihabitat and singlehabitat sample types was 54.9 and 43.6, respectively. Only one site (10) had a greater mean MMI value from a sample collected using the single-habitat methods.

Results from the two-way ANOVA tests evaluating differences between the MMI versions were similar. The test using data collected with single-habitat sampling methods indicated that the mean MMI values produced by the MMI2010 versus the MMI-2017 were indistinguishable $(p=0.757$; fig. 5). Likewise, the two-way ANOVA results using multihabitat data indicated there was no significant difference $(p=0.509)$ between the mean MMI values produced by the different versions of the MMI (fig. 6). These results indicate that the MMI values were not influenced by the MMI version, and these differences were consistent within the two sample types.

\section{Major Findings}

Results from this analysis confirm previous results (Zuellig and others, 2014) indicating consistency in sampling method comparability between the 2010 and 2017 MMI versions. Multihabitat and single-habitat sample types produced statistically different MMI values; however, MMI values were indistinguishable within sample type (multihabitat and single-habitat sample types) regardless of the sampling method (USGS or CDPHE) used. Based on the results of this study, the continuation of multihabitat sampling using USGS protocols is warranted and will provide continuity with previously collected data.

\section{Summary}

Colorado Springs City Engineering and Colorado Springs Utilities are concerned about data continuity if previously used sampling methods are replaced by the methods the Colorado Department of Public Health and Environment currently uses to assess biological condition. To address this issue, the U.S. Geological Survey (USGS), in cooperation with Colorado Springs City Engineering and Colorado Springs Utilities, analyzed previously collected invertebrate data to determine if the sampling method or different versions (2010 and 2017) of the Colorado Benthic Macroinvertebrate Multimetric Index (MMI) produced comparable assessment of biological 


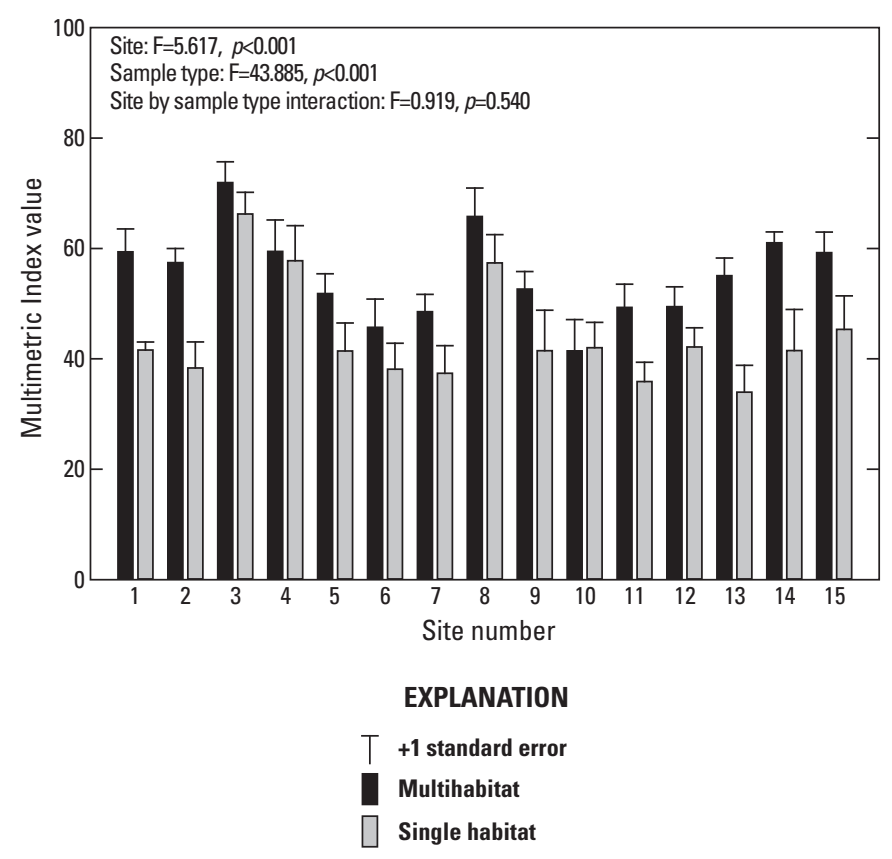

Figure 4. Mean Multimetric Index (MMI) values (+1 standard error) calculated with the Multimetric Index-2017 from 204 multihabitat and single-habitat samples collected in 2010-2012 from 15 sites in the Fountain Creek Basin in Colorado. Site information is provided in table 1. (F, F-ratio; p, probability; $<$, less than).

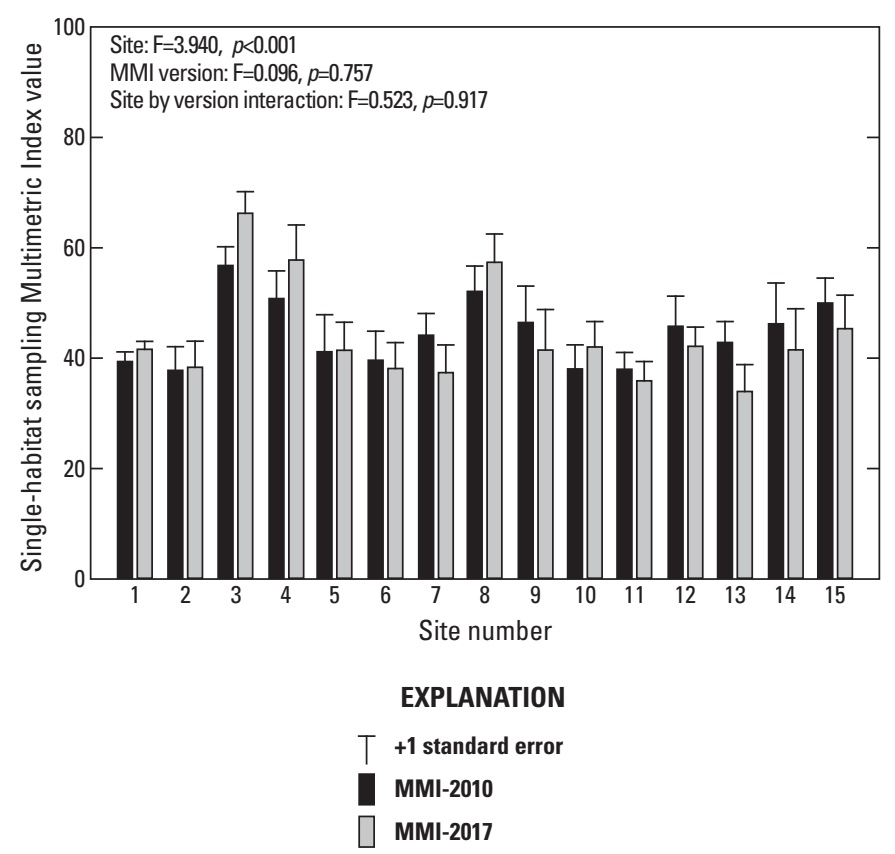

Figure 5. Mean Multimetric Index (MMI) values (+1 standard error) comparing the MMI-2010 and MMI-2017 results from 102 single-habitat samples collected in 2010-2012 from 15 sites in the Fountain Creek Basin in Colorado. Site identification information is provided in table 1. (F, F-ratio; p, probability; $<$, less than).

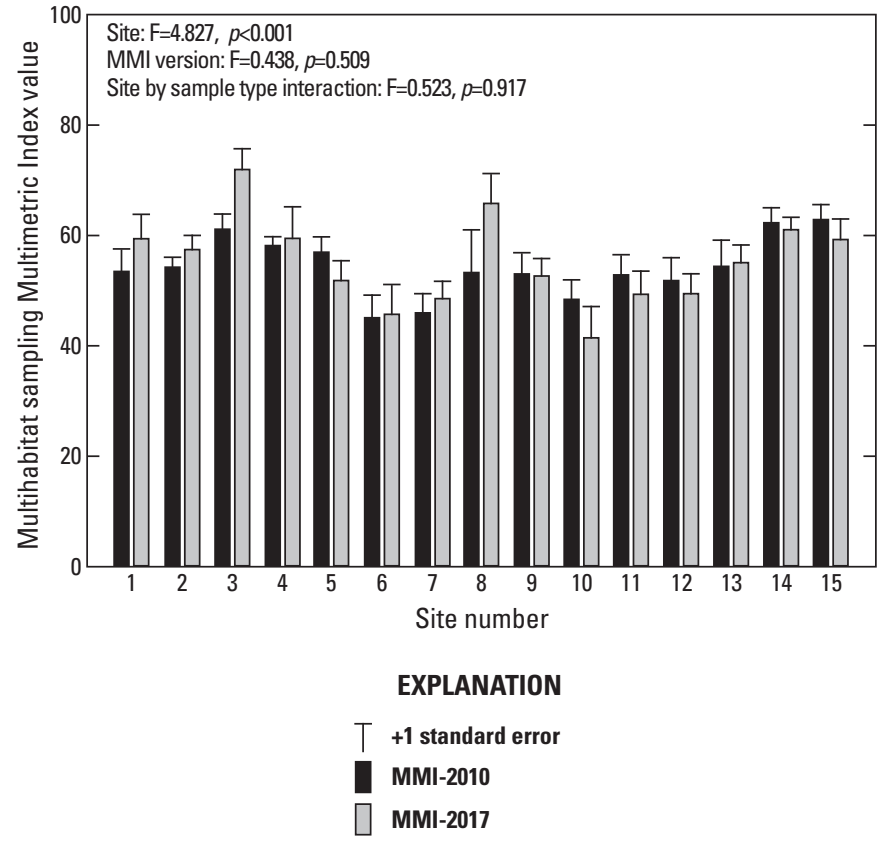

Figure 6. Mean Multimetric Index (MMI) values (+1 standard error) comparing the MMI-2010 and MMI-2017 results from 102 multihabitat samples collected in 2010-2012 from 15 sites in the Fountain Creek Basin in Colorado. Site information is provided in table 1. (F, F-ratio; $p$, probability; $<$, less than).

condition. In this study, annual macroinvertebrate samples were collected concurrently (in space and time) at 15 USGS surface-water gaging stations in the Fountain Creek Basin from 2010 to 2012 using 4 sampling methods, 2 of which are used in the USGS monitoring project and 2 of which are recommended by the Colorado Department of Public Health and Environment. Analysis of variance tests were used to compare these data. Significant differences were found between the mean MMI values obtained from multihabitat and single-habitat sample types, but the sample methods within the sample types were indistinguishable using the MMI-2010 and MMI-2017 values. The two-way analysis of variance test, with sample type and site as factors, indicated that the mean MMI values were significantly different between samples collected using multihabitat and single-habitat sample types. Results from the two-way analysis of variance tests evaluating differences between the MMI versions were similar in that the mean MMI values produced by the MMI-2010 versus the MMI-2017 were indistinguishable. Results from this analysis confirm previous results from a USGS study and indicate that Fountain Creek Basin invertebrate communities collected with similar sample type (that is, multihabitat or single-habitat sample types) using USGS or Colorado Department of Public Health and Environment sample methods are comparable. Based on the results of this study, the continuation of multihabitat sampling using USGS protocols is warranted and will provide continuity with previously collected data. 


\section{References Cited}

Carlisle, D.M., and Woodside, M.D., 2013, Ecological health in the Nation's streams: U.S. Geological Survey Fact Sheet 2013-3033, 6 p. [Also available at https://pubs.usgs.gov/ fs $/ 2013 / 3033 /$.

Colorado Department of Public Health and Environment [CDPHE], Water Quality Control Commission [WQCC], 2010, Aquatic life use attainment-Methodology to determine use attainment for rivers and streams, Policy Statement 10-1: Colorado Department of Public Health and Environment, 111 p., accessed April 8, 2013, at http://www.colorado.gov/cs/Satellite/CDPHE-WQCC/ CBON/1251590854258.

Colorado Department of Public Health and Environment [CDPHE], Water Quality Control Commission [WQCC], 2017, Aquatic life use attainment-Methodology to determine use attainment for rivers and streams, Policy Statement 10-1: Colorado Department of Public Health and Environment, 167 p., accessed September 14, 2017, at https://www.colorado.gov/pacific/sites/default/files/ Policy\%2010-1_Appendices.pdf.

Cuffney, T.F., Gurtz, M.E., and Meador, M.R., 1993, Methods for collecting benthic macroinvertebrate samples as part of the National Water-Quality Assessment Program: U.S. Geological Survey Open-File Report 93-406, 66 p. [Also available at https://pubs.er.usgs.gov/publication/ofr93406.]

Edelmann, P., Ferguson, S.A., Stogner, R.W., Sr., August, M., Payne, W.F., and Bruce, J.F., 2002, Evaluation of water quality, suspended sediment, and stream morphology with an emphasis on effects of stormflow on Fountain and Monument Creek Basins, Colorado Springs and vicinity, Colorado, 1981 through 2001: U.S. Geological Survey WaterResources Investigations Report 02-4104, 59 p.

Hansen, W.R., Crosby, E.J., and Shroba, R.R., 1982, Environmental geology of the Front Range urban corridor and vicinity, Colorado, with a section on physical properties and performance characteristics of surficial deposits and rock units in the Greater Denver area: U.S. Geological Survey Professional Paper 1230, 99 p.

Jaccard, P., 1912, The distribution of flora in the alpine zone: New Phytologist, v. 11, p. 37-50.

Jessup, B.K., 2010, Recalibration of the Macroinvertebrate Multi-Metric Index for Colorado: Montpelier, Vermont, Tetra Tech, Inc., Center for Ecological Sciences, variable pagination.
Jessup, B.K., and Stribling, J.B., 2017, Recalibration of the Colorado Benthic Macroinvertebrate Multimetric Index 2017: Denver, Colo., Colorado Department of Public Health and Environment, Water Quality Control Division, Environmental Data Unit, prepared by Tetra Tech, Inc., 68 p.

Klemm, D.J., Lewis, P.A., Fulk, F., and Lazorchak, J.M., 1990, Macroinvertebrate field and laboratory methods for evaluating the biological integrity of surface waters: U.S. Environmental Protection Agency, EPA/600/4-90/030, 256 p.

Mau, D.P., Stogner, R.W., Sr., and Edelmann, P., 2007, Characterization of stormflows and wastewater treatment-plant effluent discharges on water quality, suspended sediment, and stream morphology for Fountain and Monument Creek watersheds, Colorado, 1981-2006: U.S. Geological Survey Scientific Investigations Report 2007-5104, 76 p.

Moulton, S.R., II, Kennen J.G., Goldstein, R.M., and Hambrook, J.A., 2002, Revised protocols for sampling algal, invertebrate, and fish communities as part of the National Water-Quality Assessment Program: U.S. Geological Survey Open-File Report 02-150, 75 p. [Also available at http://pubs.usgs.gov/of/2002/ofr-02-150/.]

Omernik, J.M., 1987, Ecoregions of the conterminous United States: Annals of the Association of American Geographers, v. 77, p. $118-125$.

Roberts, J.J., Bruce, J.F., and Zuellig, R.E., 2018a, Changes in biological communities of the Fountain Creek Basin, Colorado, 2003-2016, in relation to antecedent streamflow, water quality, and habitat: U.S. Geological Survey Scientific Investigations Report 2017-5162, 20 p. [Also available at https://doi.org/10.3133/sir20175162.]

Roberts, J.J., Bruce, J.F., and Zuellig, R.E., 2018b, Multimetric Index macroinvertebrate values from the Fountain Creek Basin, Colorado 2005 to 2016: U.S. Geological Survey data release, https://doi.org/10.5066/F7VQ320K.

Sørensen, T.A., 1948, A method of establishing groups of equal amplitude in plant sociology based on similarity of species content and its application to analyses of the vegetation on Danish commons: København, I kommission hos E. Munksgaard, Biologiske skrifter, Kongelige Danske videnskabernes selskab, v. 5, p. 1-34.

Stogner, R.W., Sr., 2000, Trends in precipitation and streamflow and changes in stream morphology in the Fountain Creek watershed, Colorado, 1939-99: U.S. Geological Survey Water-Resources Investigations Report 2000-4130, $43 \mathrm{p}$.

SYSTAT, 2007, SYSTAT ${ }^{\odot} 12$ software: San Jose, Calif., SYSTAT Software Inc., 575 p. 
U.S. Environmental Protection Agency, 2006, Wadeable streams assessment-A collaborative survey of the Nation's streams: U.S. Environmental Protection Agency, EPA 841B-06-002, 117 p., accessed March 2013 at http://www.epa. gov/owow/streamsurvey/.

U.S. Geological Survey [USGS], 2017a, BioData-Aquatic bioassessment data for the Nation: U.S. Geological Survey, accessed November 16, 2017, at http://dx.doi.org/ doi:10.5066/F77W698B.

U.S. Geological Survey [USGS], 2017b, USGS water data for the Nation: U.S. Geological Survey National Water Information System database, accessed [November 10, 2017], at https://doi.org/10.5066/F7P55KJN.

von Guerard, Paul, 1989, Sediment-transport characteristics and effects of sediment transport on benthic invertebrates in the Fountain Creek drainage basin upstream from Widefield, southeastern Colorado, 1985-88: U.S. Geological Survey Water-Resources Investigations Report 89-4161, 133 p.

Zuellig, R.E., Bruce, J.F., Evans, E.E., and Stogner, R.W., 2007, Urban-related environmental variables and their relation with patterns in biological community structure in the Fountain Creek Basin, Colorado, 2003-2005: U.S. Geological Survey Scientific Investigations Report 2007-5225, $24 \mathrm{p}$.

Zuellig, R.E., Bruce, J.F., Stogner, R.W., 2010, Temporal change in biological community structure in the Fountain Creek Basin, Colorado, 2001-2008: U.S. Geological Survey Scientific Investigations Report 2010-5103, 19 p.

Zuellig, R.E., Bruce, J.F., Stogner, R.W., and Brown, K.D., 2014, Comparability among four invertebrate sampling methods, Fountain Creek Basin, Colorado, 2010-2012: U.S. Geological Survey Scientific Investigations Report 2014-5049, 13 p. 
Publishing support provided by the Science Publishing Network, Denver and Lafayette Publishing Service Centers

For more information concerning the research in this report, contact the Director, USGS Colorado Water Science Center

Box 25046, Mail Stop 415

Denver, CO 80225

(303) 236-6900

Or visit the Colorado Water Science Center website at https://co.water.usgs.gov/ 



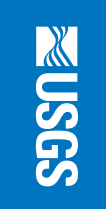

ISSN 2328-0328 (online) 